\title{
The management of expatriates: contemporary developments and future challenges
}

The rapid growth of international business at a time when many multinational companies (MNCs) are under increasing cost pressures has led these organisations to take a much closer look at their expatriation policies and practices. Faced with unprecedented levels of foreign competition at home and abroad, firms are beginning to recognise not only that international business is high on top management's list of priorities but that finding and nurturing the human resources required to implement an international strategy is of critical importance (Dowling et al., 1994). Much of the research on the management of expatriates currently available is drawn from research focused on North American multinationals. Adler (1997) commented that most research on international human resource management was concerned with American expatriates and continues to be written from an American rather than an international perspective. This introduction seeks to highlight the growth of research into expatriation to set the context for the five papers in this special edition that both add to some traditional areas of expatriate research and open up new fields relevant to this area of enquiry in international management and international business.

An understanding of the management of expatriates is of growing importance at the present time for a number of reasons outlined below (see Scullion, 2001):

- As MNCs increase in influence and number associated with rapid increases in global activity, so the role of expatriates in those MNCs increases in significance (Black et al., 1999).

- The effective management of expatriates is increasingly been recognised as a major determinant of success or failure in international business (Black and Gregerson, 1999).

- Research suggests that many international firms had experienced shortages of international managers, which often acts as a significant constraint on the implementation of international growth strategies (Price Waterhouse Europe, 1997/1998).

- The rapid growth of smaller and medium sized enterprises (SMEs) that have internationalised their operations in recent years means that issues of expatriate management are increasingly important concerns in a far wider range of organisations than the traditional giant multinationals (Brewster and Scullion, 1997).

- It is increasingly recognised that the human and financial costs of underperformance/failure in the international business area are considerably more severe than in the domestic area. There is also evidence that many companies relatively new to the international scene underestimate the complex nature of human resource (HR) problems in the international arena and that business failures in the international arena may often be linked to the poor performance of expatriates (Forster, 2000).

In general terms, the study of expatriation has followed the traditional expatriate "cycle" - selection, training, relocation and adjustment, pay and performance and return, with early attention on the earlier stage of the assignment and a successively developing focus on the later and more complex issues of performance and repatriation (Scullion and Brewster, 2001). Baruch and Altman (1999) found that 
much research dealing with expatriation has been concerned with individuals lacking in conceptual work at the organisational or human resources operational level. Linehan (2000), Adler (1997) and Harris (1995) suggest that expatriate management has long been a masculine preserve in the USA and Europe, with little research conducted with European female expatriates, mainly due to their relative scarcity. According to Adler (2002), as global competition intensifies, the opportunity cost of relying on the traditional male expatriate escalates. Most global managers know their companies can no longer afford to ignore potential talent "simply because it's wearing a skirt" or because it holds a passport different from that of the founding executives (Fisher, 1992).

The empirical research on trends in international staffing policies, in addition to identifying the reasons for employing expatriates, also revealed some interesting differences between North American and UK firms with the latter using longer assignments and relying more heavily on expatriates to control overseas operations (Scullion, 2001). Recent European research highlights the importance of country specific factors and points to the differences between countries in staffing practices. Harzing's (1999) study, for example, shows Japan and Germany at one extreme with a high level of expatriate presence while the USA was at the other extreme.

Recent research has highlighted that not all cross-border business activities are staffed by "traditional" expatriates, that is, expatriates on international assignments lasting several years. Increasingly, purchasing and sales activities are conducted by people on short (often, literally flying visits). The development of travel and technology is making such "substitute" expatriate activities more common, particularly in Europe. Euro commuting or frequent flying is becoming increasingly common (Petrovic et al., 2000; Mayrhofer and Scullion, 2002) and the increasing use of video conferencing and real time computer information from around the world has provided alternatives to control by the physical presence of an expatriate. The implications of these developments for the management of expatriates remain largely unresearched, but they may have considerable implications for MNCs (Scullion and Brewster, 2001).

Research into the recruitment and selection of expatriates is often highly prescriptive and has generally been focused on issues such as selection criteria. Recent European research, however, highlights that in practice decisions on expatriate selection are usually taken by line managers - who often simply ignore the selection decisions espoused by the HR department (Brewster and Harris, 1999). Research also suggests that European companies pay closer attention to the selection of expatriates, perhaps reflecting the greater importance of international revenues for European MNCs relative to US MNCs. Also research suggests that international experience was more highly valued in European MNCs, and expatriate assignments were regarded as high status and often integral to the management development process (Price Waterhouse Europe, 1997/1998).

Training and development programmes for expatriates are more common in European than in US MNCs. Research shows that cultural awareness training remains the most common form of pre-departure training for expatriates but that other forms of preparation - briefings, shadowing, look-see visits - are more frequent than formal training programmes and may be more cost effective (Brewster and Scullion, 1997). A recent trend is that European MNCs are extending their pre-departure training 
programmes to include the partner and children, reflecting the growing awareness of the link between expatriate performance and family adjustment (Linehan and Scullion, 2002). Finally, several influential models of training and development for expatriate management have been developed including contingency models which consider the task, the individual and the environment before deciding the depth of training required (see Black et al., 1999). Recent research, however, suggests that the development of international managers in the future will involve more frequent crossborder job swaps, short assignments, or assignments to multi-cultural project teams (Forster, 2000).

Issues of expatriate adjustment have been highlighted in recent research in central and eastern Europe (CEE) which shows that local managers in these countries often resent the attitude of Western expatriate managers who are seen as unwilling to take into account the views of local people (Cyr and Schneider, 1996). Morley et al. (1997) address the extent to which frameworks of international adjustment, developed primarily in the North American context, are applicable to the transition economies of the CEE. They suggest that a detailed understanding of the context of adjustment in each case is therefore seen to be important in determining which variables are likely to cause problems.

The whole question of performance measurement and management in multinational companies involves a complex range of issues, and research to date suggests that rigorous performance appraisal systems for expatriates are far from universal (Schuler et al., 1991; Brewster and Harris, 1999). This is perhaps surprising given the high costs of expatriate underperformance and the growing tendency to see expatriates as key strategic human assets (Black and Gregerson, 1999). Research suggests that European multinationals are more likely to pay close attention to this aspect of expatriation and tend to evaluate managers more on the achievement of long term goals than the short term measures used by US multinationals (Lindholm et al., 1999). In part this reflects the growing use of international assignments for developmental purposes in European multinationals and the greater integration of expatriation into the overall career development process (Scullion, 2001). However, recent research highlights the considerable differences in the way the appraisal process is actually handled in different countries. Tahvanainen (1998) found that in Sweden and Germany, for example, it is normal for staff to participate in the setting of job goals, whereas in the USA setting job goals is the priority of management. Also, problems in cultural adjustment which may have an impact on work performance should be considered when assessing an expatriate's performance in a new role (Lindholm et al., 1999).

The repatriation of expatriates has been identified as a major problem for MNCs in Europe and North America (Black et al., 1999; Linehan and Scullion, 2002). A recent study showed that a majority of US managers were satisfied with expatriation, while a majority were unhappy with repatriation (Tung, 1998). Indeed, concern over re-entry was cited as a significant reason affecting expatriate performance (Scullion, 2001) and North American academics have made a major contribution to our understanding of repatriate adjustment (see Black et al., 1999). Many expatriates leave their company on return with the consequent loss of investment and expertise. This loss of investment and international knowledge has led to calls for a more strategic approach to repatriation (Linehan and Scullion, 2002). Yet, while it is widely accepted that the 
costs of expatriate turnover are high, very few firms have effective repatriation programmes. Recent research shows that the management of repatriation is more complex in decentralised multinational companies and yields some insights into how the repatriation process can be used to develop the internationalisation of organisations (Scullion and Starkey, 2000). Research evidence suggests that between 20 per cent and 50 per cent of all expatriates resign - a significantly higher percentage than among non-repatriate executives (Black and Gregerson, 1998). In practice, many organisations continue to adopt an ad hoc, sink or swim attitude in relation to repatriation for employees and their families, and many expatriate managers continue to experience the repatriation process as falling far short of expectations (Stroh et al., $\underline{1998)}$.

Finally, the handling of expatriation issues is a crucial role in the competitiveness of organisations. The traditional parameters of human resource management may prove insufficient to deal with mobility needs or with the willingness of managers to accept transfers. Vanderbroeck (1992) emphasises the possible effects on international mobility because of changing value systems in western countries. In most western societies the percentage of two-career families is high, and particularly when a transfer means that a partner must sacrifice a personal career, this can make recruitment quite difficult. The recent fashion for "quality of life" issues over materialistic values means that organisations that make career success conditional on acceptance of overseas assignments might find it difficult to retain good talent. Similarly, when home-country organisations do not value expatriate experience and fail to make positive use of repatriated employees, this can discourage new candidates from accepting expatriate assignments.

This special issue of the Journal of Managerial Psychology presents five selected papers that, in various ways, investigate aspects of expatriate management that have been part of the mainstay of research in this area heretofore, along with more recent developments that may acquire a pedigree in the field into the future.

In our first paper, Vesa Suutari from the University of Vaasa in Finland focuses on global managers who are committed to international careers over the longer term. The author starts from the premise that much extant research does not provide empirical evidence on the careers of those who relocate internationally on a relatively frequent basis. He notes from his trawl of the literature that the focus of much of the research on international careers has been on those expatriates who decide to repatriate permanently back to their home country following a period on foreign assignment. The central research question being addressed here is what are positive and negative implications of what are described as "aspatial" careers for expatriates and their families. Through detailed semi-structured interviews with 24 Finnish managers, the author presents new empirical evidence on the career orientation, career traits, lifestyle implications and the career commitment of these managers.

In the career orientation sphere, the author identifies two different kinds of managers, namely those among whom internationalisation has played an important role in their career orientation and a separate group who in their early careers demonstrated no clear intention to seek out an international career. Common among both of these types however, was a generally positive experience on their first assignment. With respect to their career tracks, the data demonstrate that assignees operate across several 
countries during their careers, depending on emerging company needs. International careers among this sample were typically of two types, namely a group who alternate between international and home assignments and another group who typically move from one international assignment directly on to another international move. In terms of the impact of these international careers on personal and family life, the author notes that those in this sample typically report that personal relationships are more difficult to maintain. So too, is striking the correct balance between work and family/personal life and an ongoing requirement for adjustment by both the assignee and his/her family was nominated as an important issue. Finally, in terms of their commitment to their international career, the majority of interviewees in this sample indicated that they would not abandon the international dimension to their work and career. Rather they demonstrated a high commitment to this international element of their careers and to its value as a means of securing organisational success into the future.

The focus of our second paper in this issue switches from the international assignee to that of the local employee working for the international firm. Drawing on data gathered among 317 local managers at the Indian and Pakistani subsidiaries of a British MNC, Carol Reade of the University of Sri Jayewardenepura in Sri Lanka focuses on what it takes to motivate such local employees. The author examines the extent to which a number of variables enhance the inclination of local managers to exert effort for the benefit of the MNC as a global entity, as well as for their local company. Here organisational identification, described as the psychological bonding between the individual and the organisation, is viewed as being of primary importance. Other variables that are seen to buttress this are both supervisory support for the local employee and local employees' perceived access to the organisational hierarchy, regardless of nationality. From her review of the extant literature, the author notes that identification with the organisation has long been posited as an important determinant of the effort that one exhibits in the workplace to the point where a perceived oneness with the organisation suggests a merging of organisational and individual identities. This, the author notes, is in contrast to the situation where pragmatism or instrumental motivation are the order of the day. Despite its importance as a central tenet of organisational success, understanding the nature of the identity one has with the organisation in the MNC context is not straightforward. Indeed the author notes that research in organisational identification is relatively sparse and applications to the MNC context are particularly rare. Here, Reade draws on social identify theory to illustrate whether local managers make a distinction between what they will do for the "local subsidiary" and what they will do for the "global organisation" and she advances a set of antecedents of organisational identification in MNCs. The results of the investigation show a clear distinction between "effort for the local company" and "effort for the global organisation" with local managers perceiving a difference between their local company and the global organisation in terms of their willingness to exert effort. While in general, local managers were more willing to expend effort for the local company than for the global organisation, those at the Pakistani subsidiary did not appear to make this distinction. A multiple regression reveals that organisational identification did have a significant impact of effort, with local identification having a significant impact on local effort and global identification being significant in the context of global effort. Beyond identification, the analysis reveals that local effort is positively influenced by, among other things, the prestige and distinctiveness of the local company and 
negatively impacted by a preference for cultural similarity in the workplace. Concomitantly, global effort is positively impacted by support of superiors at the MNC headquarters and nationality not acting as a barrier to promotion at the global level, while interpersonal relations with peers at the global level emerges as having a potential negative impact on global effort. The author concludes by identifying the implications of this work for expatriate managers and for international human resource management more broadly.

Our third contribution by Guthrie, Ash and Stevens, is one of two papers in this issue to focus specifically on female international assignees. Drawing on data from 1,080 university students through the administration of the NEO-PI-R or the Hogan personality inventory, both of which measure the "big-five" personality dimensions, Guthrie et al. focus on personality differences and expatriate selection and ask whether "women are better than men?". The authors note that gender in global assignments has attracted increasing attention in the extant academic literature in recent years and, drawing on Caligiuri et al., they outline three particular types of studies as follows:

1. those that focus on gender differences in the procurement of global assignments;

2. those that focus on gender differences in the outcome of global assignments; and

3. those that focus on gender differences and the predictors of global assignee success.

The contribution in this volume falls into the latter category and provides an assessment of gender-based personality differences and their likely implications for hiring international assignees. The authors offer a focused review of literature in the areas of personality assessment and work performance, personality characteristics and expatriate success and gender differences and international assignments. The authors apply both a top-down and minimum competency selection approach to the data and generate 32 different selection outcomes in which to examine gender. They create an "expatriate composite score" and select individuals from four different applicant pools for a hypothetical expatriate assignment. With respect to the results, in all the 32 scenarios examined, regardless of which personality instrument is deployed, the proportion of females selected is greater than the proportion of males selected and statistical results confirm that the use of personality criteria do result in gender being significantly associated with selection outcomes. While acknowledging the limitations which attach to the research effort here, the authors note that, derived from a personality approach to selection, the results support the argument that women as a group, may be somewhat better suited to foreign assignments than their male counterparts.

Selmer and Leung also focus on female expatriates and offer new data on western female business expatriates in Hong Kong $(n=343)$. They note that, despite the acknowledged necessity to broaden the talent pool, the share of women sent on foreign assignment remains far less than their male counterparts and, in support of Guthrie et al. in the previous paper, they note that women must be very determined to overcome preconceived ideas of decision-makers at headquarters to become selected for an expatriate assignment. Here the authors focus on how the career intentions of 
female expatriates are related to their international adjustment. Following from a review of literature in the area of expatriate careers and international adjustment, two core hypotheses are advanced, namely:

H1. Expatriate career intentions have a positive association with sociocultural adjustment

H2. Expatriate career intentions have no associations with psychological adjustment

Both are subsequently investigated using hierarchical regression analysis. In this investigation career intentions were measured by a five-item self-developed scale, sociocultural adjustment based on previous work and psychological adjustment through the General Health Questionnaire. The results first suggest that the female expatriates in this study score well on the "general adjustment" scale and the "interaction adjustment" scale. Their work adjustment scores are also high. Combined, the authors suggest that this may indicate that these female expatriates were quite comfortable with their sociocultural environment. Along the psychological adjustment dimension, the scores were also above the mid-point and the career intentions scores suggested that assignees intended to pursue their international career. The results from the subsequent regression analysis provide partial support for $H 1$ and do support $H 2$. Thus, the more determined the women are to pursue an expatriate career, the better is their interaction adjustment. However, as indicated, determination to pursue such a career was not associated with the psychological adjustment of the expatriates in this sample. Importantly, by way of implications, Selmer and Leung note that female employees with international career plans can be reassured that it is possible for determined women to succeed in their foreign assignment and their career intentions, combined with an "interactive" approach to the host culture, may, the authors suggest, be a valuable asset in the struggle to ensure success abroad. The authors conclude by offering a number of directions for future research, which could prove fruitful in unravelling aspects of the female international career area.

The final paper in this issue focuses on expatriate stories and their use as a potential vehicle for processional development. Here Lyn Glanz draws on narrative to examine expatriate experience and suggests that such an approach can prove valuable to the expatriate in his/her efforts to understand the novelty of their host environment. The author draws on "sensemaking" as a theoretical framework for the investigation and the subsequent reportage. Sensemaking, viewed as the process whereby we use conscious rational thought to re-analyse and bring order to confusion and surprise, is offered by the author as a workable framework for understanding aspects of the expatriate experience and the use of narrative or storytelling may be thought of as a lens through which we can observe sensemaking in action. In this regard the author notes that conventional quantitative measures are difficult to employ when investigating sensemaking and suggests that narrative may offer an alternative way forward in our attempts to map the fluidity of sensemaking. In this paper the author draws on 11 narratives collected from four different sources between 1995 and 2002 and which are designed to illustrate the properties of sensemaking. Importantly, all are drawn from actual expatriate experience in an attempt to provide "narrative of the actual" and provide different insights into a variety of environments encountered. The 
author concludes by reiterating the value of understanding the informal and alerting the reader to the potential value of this approach as a window into both the actual expatriate experience and as a mechanism for the professional development of assignees more generally.

\section{Michael J. Morley, Margaret Linehan, Hugh Scullion}

\section{References}

Adler, N.J. (1997), International Dimensions of Organizational Behaviour, PWSKent, Boston, MA

Adler, N.J. (2002), "Global managers: no longer men alone", The International Journal of Human Resource Management, Vol. 13 No. 5, pp. 743-60

Baruch, Y. and Altman, Y. (1999), "Expatriation and repatriation in MNCs: a taxonomy", paper presented at Academy of Management Conference, Chicago, IL, 611 August.

Black, J.S. and Gregerson, H.B. (1998), So You're Going Overseas: A Handbook for Personal and Professional Success, Global Business Publishers, San Diego, CA Black, J.S. and Gregerson, H.B. (1999), "The right way to manage expats", Harvard Business Review, March/April , pp. 52-63

Black, J.S., Gregerson, H.B., Mendenhall, M.E. and Stroh, L.K. (1999), Globalizing People through International Assignments, Addison-Wesley, Reading, MA

Brewster, C. and Harris, H. (Eds) (1999), International HRM: Contemporary Issues in Europe, Routledge, London

Brewster, C. and Scullion, H. (1997), "A review and agenda for expatriate HRM", Human Resource Management Journal, Vol. 7 No. 3, pp. 32-41

Cyr, D. and Schneider, S. (1996), "Implications for learning: human resource management in east-west joint ventures", Organization Studies, Vol. 17 No. 2, pp. 201-26

Dowling, P., Schuler, R. and Welch, D. (1994), International Dimensions of Human Resource Management, Wadsworth, Belmont, CA

Fisher, A.B. (1992), "When will women get to the top?", Fortune, Vol. 21, pp. 44-56 Forster, N. (2000), "The myth of the international manager", International Journal of Human Resource Management, Vol. 11 No. 1, pp. 126-42

Harris, H. (1995), “Women's role in (international) management", in Harzing, A.W. and Van Ruysseveldt, J. (Eds), International Human Resource Management: An Integrated Approach, Sage, London, pp. 229-51

Harzing, A.W.K. (1999), Managing the Multinationals: An International Study of Control Mechanisms, Edward Elgar, Cheltenham

Lindholm, N., Tahvanainen, M. and Bjorkman, I. (1999), "Performance appraisal of host country employees: Western MNEs in China", in Brewster, C. and Harris, H. (Eds), International HRM: Contemporary Issues in Europe, Routledge, London Linehan, M. (2000), Senior Female International Managers: Why So Few?, Ashgate, Aldershot

Linehan, M. and Scullion, H. (2002), "Repatriation of European female corporate executives: an empirical study", International Journal of Human Resource Management, Vol. 13 No. 2, pp. 254-67

Mayrhofer, W. and Scullion, H. (2002), "All equal? The importance of context empirical evidence about male and female expatriates from the German clothing industry", International Journal of Human Resource Management, Vol. 3 No. 5, pp. 
815-36

Morley, M., Burke, C. and Flynn, G. (1997), "The Irish in Moscow: a question of adjustment", Human Resource Management Journal, Vol. 7 No. 3, pp. 53-66 Petrovic, J., Harris, H. and Brewster, C. (2000), "New forms of international working", Crème Research report, 1/00, Cranfield School of Management, Cranfield University, Cranfield.

Price Waterhouse Europe (1997/1998), International Assignments: European Policy and Practice, Price Waterhouse International Assignment Services Europe Schuler, R.S., Fulkerson, J.R. and Dowling, P.J. (1991), "Strategic performance measurement and management in multinational corporations", Human Resource Management, Vol. 30, pp. 365-92

Scullion, H. (2001), "International human resource management", in Storey, J. (Ed.), Human Resource Management: A Critical Text, International Thompson, London Scullion, H. and Brewster, C. (2001), "The management of expatriates; messages from Europe", Journal of World Business, Vol. 36 No. 4, pp. 346-65 Scullion, H. and Starkey, K. (2000), "The changing role of the corporate human resource function in the international firm", International Journal of Human Resource Management, Vol. 11, pp. 1061-81

Stroh, L., Gregersen, H.B. and Black, J.S. (1998), "Closing the gap: expectations versus reality among repatriates”, Journal of World Business, Vol. 33 No. 2, pp. 11124

Tahvanainen, M. (1998), "Expatriate performance management. The case of Nokia Telecommunications", Helsinki School of Economics and Business Administration, Helsinki.

Tung, R.L. (1998), "American expatriates abroad: from neophytes to cosmopolitans", Journal of World Business, Vol. 33 No. 2, pp. 125-44

Vanderbroeck, P. (1992), "Long-term human resource development in multinational organizations", Sloan Management Review, Vol. 33 , pp. 95-9 